\title{
BRAZILIAN FEDERAL INSTITUTES AND CANADIAN COLLEGES: SHARING EXPERIENCES INTERNATIONALLY
}

\author{
CLAUDIA SCHEDEECK SOARES DE SOUZA \\ FEDERAL INSTITUTE OF EDUCATION, SCIENCE AND TECHNOLOGY OF RIO GRANDE DO SUL - IFRS
}

\begin{abstract}
The Brazilian Federal Network of VET Institutes was created in 2008 to address the demand for Higher Education's rapid growth. Since the establishment of Science Without Borders in 2011, the Federal Institutes have been developing international strategies for strengthening their internationalization process. However, there has been little research about the theme in Brazil. This article highlights the cooperation between Canada and Brazil that enhanced the Federal Institutes' internationalization process. The findings presented in this article are part of the research results on the Brazilian Federal Institutes' internationalization model, which used Situational Analysis as a methodological tool and pointed to the A Thousand Women project as the first significant international experience in these institutions. The data analyzed supports the claim that Canada became a significant reference for the Brazilian Federal Institutes and helped them build their internationalization process concretely and collaboratively.
\end{abstract}

Keywords: VET, Federal Institutes, Internationalization, Canada, Brazil

\section{Résumé}

Le Réseau des Instituts fédéraux de formation professionnelle et technologique du Brésil fut créé en 2008 afin de répondre à la demande pour une croissance rapide de l'enseignement supérieur au pays. Depuis le programme " Sciences sans frontières » en 2011, les instituts fédéraux ont développé des stratégies internationales afin de renforcer leurs processus d'internationalisation. Cependant, il y a très peu de recherche sur cette thématique au Brésil. Cet article met en valeur le rôle que la coopération entre le Canada et le Brésil a pu jouer dans l'amélioration du processus d'internationalisation au sein des instituts fédéraux. Les constats présentés dans cet article sont le résultat d'une recherche sur le modèle d'internationalisation adopté par les instituts fédéraux. Cette recherche s'est basée sur une méthodologie d'analyse de situation et met en exergue le rôle du projet des " Mille femmes » en tant que première expérience internationale au sein de ces établissements. L'analyse des données confirme que le Canada est devenu une référence importante pour les instituts fédéraux brésiliens et les a aidés de manière concrète et solidaire à renforcer leur processus d'internationalisation.

Mots-clés : formation professionnelle et technologique, instituts fédéraux, internationalisation, Canada, Brésil

\section{Introduction}

Internationalization in education has been widely discussed and analyzed to the extent of the educational research field, both for its increasing importance as a consumer good in the globalized world and for its relevance for educational policies of Higher Education institutions (Altbach \& Knight, 2007; Helms et al., 2015; Wit et al., 2017). In Brazil, academic debate about this sub- ject is much more recent since universities' creation is a phenomenon of just over 100 years. However, it gained momentum during the last years of the 1990s when the country opened itself more consistently to imports and global competitiveness (Morosini \& Dalla Corte, 2018).

Although Vocational Educational and Training (VET) had also been affected by globalization's consequences, research on VET's internationalization process has been relegated to a secondary level (Tran \& Dempsey, 
2017). This educational stream has little social status worldwide and is linked with the individuals who did not have the needed skills or budget to go to universities (Wheelahan \& Moodie, 2017, 2018). So far, there is little investment for VET institutions. These reasons could influence funding for research projects and academic production to register experiences, raise data, or present relevant internationalization factors into the Professional Education ${ }^{1}$ field.

It is beyond doubt that globalization, neo-liberal policies, and transnational companies have a significant impact on training programs, mainly because they are to be built anticipating skills and knowledge that spread along with the evolution of technology (Levin, 2017; Tran \& Dempsey, 2017).

This article aims to present part of the findings of research on the internationalization field on the extent of the Professional Education discipline that can highlight the importance of the relationship established between Canadian Colleges and Brazilian Federal Institutes (FIs), primarily through the $A$ Thousand Women program, which still today remains as an example of meaningful international cooperation for the Brazilian Institutes' network. This outcome was fundamental during a qualitative and exploratory investigation, which used Situational Analysis (Clarke et al., 2018) as a methodological tool. Even though this investigation's initial goal was to seek the Fls internationalization model, the data showed the relevance of Canadian Institutions as partners and an example of fruitful synergy.

The data findings show that Canada and Brazil's relationship in the professional education field is grounded in the literature that advocates respect for the local context and commitment to the actors' strategies in the internationalization process as essential features for successful outcomes cooperation. However, further research is needed to understand how it escaped from the competitive and marketized worldwide internationalization pattern.

\section{Literature Review}

World educational systems, in general, are not immune to globalization and are influenced by international organizations that offer solutions, models, and consultancies not only on improving the quality of education but also on accountability, especially in developing countries, to influence public policies (Ball, 2012; Dale, 2000). The quality and productivity demand dramatically affect Higher Education Systems due to universities' pressure to become internationalized and a consumer good (Waldow, 2018). If there is an international dimension present in Higher Education (and surely there is), according to Tran and Dempsey (2017), it is not possible to disconnect Professional Education institutions from globalization since they have close ties with the workforce and firms in each country.

Although globalization and internationalization can be analyzed as distinctive processes, they are related to each other. As Knight $(2004,2012)$ noted, the internationalization landscape's complexity demands a more neutral definition to comprise most types of actors, arrangements, activities, and projects involved in it worldwide. This concept must be able to embrace the rationales driving the internationalization process. So, the author defines internationalization as "the process of integrating an international, intercultural, or global dimension into the purpose, functions or delivery of post-secondary education" (Knight, 2004, p. 11).

Research carried out worldwide indicates that nations split post-secondary education into two different streams: the professional education one, known internationally as vocational (VET), and the academic one. The reasons for this divergent strategic position of VET in different countries are found in their economic, cultural, and social structure and their transition of students to the labour market (Bosch \& Charest, 2009; Wheelahan \& Moodie, 2017).

Each transition system can be defined by the characteristics of institutional and structural arrangements, which mediate the labour processes and can result in high or low employability rates after the end of professional training. In coordinated market economies (CME), there are strong links between educational institutions and the world of work, which allow students to have higher chances and reasonable earnings when getting a position. This synergic pattern happens more frequently in Northern European countries, and the actors involved actively participate in structuring, updating, providing, and assessing professional education, granting a more prestigious role in the educational landscape (Raffe, 2008).

On the other hand, in countries defined as liberal market economies (LME), the transition system tends to 
be weaker. So, professional education is embedded in the overall educational system, and qualification or training programs become merely a strategy for establishing minimum skills in each job vacancy. In LMEs, relations between companies and other institutions are mediated by hierarchies, competitive arrangements, formal contracting, and, thus, being more subject to global economic changes. In such economies, responsibility for qualification and lifelong learning, as well as suitability for the job, lies primarily with students or workers. Anglophone nations stand out among the ones characterized by this arrangement (Hall \& Soskice, 2001; Wheelahan \& Moodie, 2017, 2018). Due to Brazil's economic and social characteristics, the country is aligned with Canada as a Liberal Market Economy.

Cantwell et al. (2018) point out that the global landscape changes in post-secondary education are associated with Higher Education massification (High Participation Systems). The substantial increase of HE's demand in several countries was a decisive factor for developing a new non-university, multidisciplinary, multicurricular educational sector, which integrates old and new VET institutions and is expanding worldwide at a ratio of one percent per year (Cantwell et al., 2018).

Besides, the development of Professional Education has increased its importance in the international arena, mainly due to the frequent global economic crises that follow and companies' transnationalization. Thus, the standardization of machinery and software is increasingly common and, therefore, the levels of skills needed for workers to find a place in the world of work are increasing. Maurer and Gonon (2014) point out that the transfer of educational policies or programs can be a more viable alternative for governments and institutions than developing local solutions, facilitating and legitimizing international cooperation among similar institutions.

The creation of the Federal Professional Education Network, proposed by Act 11.891/2008 (Brasil, 2008), cannot be isolated from the international trends related to the massification of Higher and Professional Education and policy transfer. It has its roots in the expansion of post-secondary education and its connection with the world of work and the conception of new educational institutions to address the need for social mobility in the post-war world (Bosch \& Charest, 2009; Cantwell et al., 2018; Didriksson, 2008).

Concerning their structural model, the Federal Insti- tutes bear similarities to other international systems of Vocational Education, specifically the French systemmore school-based, and state-regulated (Greinert, 2010; Wollschlager \& Reuter-Kumpmann, 2004). According to Dolowitz and Marsh (1996), political actors such as policy makers, experts, and government officials can borrow lessons from other institutions and countries by transferring actions, programs, and policies to provide answers to society for structural problems or tensions. Although there are no empirical or documentary studies that can support more concrete conclusions on this subject, the constitution of the Federal Network has summed up elements and characteristics of programs and systems already established outside the country, such as the offering of $\mathrm{HE}$ and curricularized applied research, without losing its origin, such as the offer of secondary integrated technical programs.

When analyzing research on policy borrowing, Steiner-Khamsi (2012) noted that signalling the differences between educational subsystems is fundamental for their survival and autonomy. This way, they insert themselves into international organizations' discourse, seeking to adopt international standards or norms.

Studies that intertwine both internationalization and VET issues are still embryonic, and much research is needed to understand how, why, and what is transferred or internationalized. This gap could be filled by comparative studies that analyze data beyond specific analysis units, such as curriculum and teacher training, and examine the institutions and the policies through broader lenses, deepening qualitative works about multicultural experiences and successful programs in different countries.

\section{Methodology}

The results presented in this article originated from research in which the central question was whether or not the Federal Institutes were developing an internationalization model. This research sought to elicit the meanings, directions, reasons, and choices of Fls' rectors and international advisors.

The lack of research about the Federal VET Network's internationalization led to qualitative exploratory and explanatory research using Grounded Theory (GT) as a methodological approach to building a theoretical framework for the theme. The Situational Analysis (SA) 
as an analytical tool for the data of the GT methodology made it possible to organize and establish the relationships between the categories that were produced by the data. Thus, this study's central aim was to establish the rationales that underlie the Federal Institutes' internationalization. Considering that different variables forge the research situation, SA proposes three types of mapping for establishing the connections between the concepts and categories: situational maps, maps of social worlds/arenas, and positional maps (Clarke et al., 2018).

To analyze the Federal Network's internationalization process and find which past, present, and future actions may have influenced it, 14 semi-structured interviews were carried out (six international advisors, five rectors, three former Ministry of Education international advisors). All Brazilian regions were included in the data, with the southeast region being more significant in numbers (with four respondents) due to the demographic representativeness and the number of Federal Institutes (eight, in total).

This article discusses the experience of internationalization developed between Canada and Brazil and lies in the Fls Map of Social Worlds/Arena analysis built during the data examination.

\section{Brazilian VET System: An Overview}

The conception of specific training programs for work arises in Brazil through Act 7566/1909 (Brasil, 1909) with the conception of the first 19 schools of apprentices and craftsmen and serving the most socially vulnerable. The schools created by this Act were established in province capitals under the responsibility of the Federal Government. Their specific goal was to provide social aid to classes excluded from the state and prevent migration, unemployment, and absenteeism in urban centres. This sort of training did not permeate the Brazilian educational system since it lacked social prestige. Instead, it produced a low-class education, which allowed the educational segmentation between institutions preparing for less valued jobs and others established to educate for more influential positions. This cleavage ensured the segregation between children of wealthier classes, who had opportunities for holistic education, and those from the least favoured ones, whose study opportunities were restricted to qualifying for jobs considered less noble.

Some of these first federal institutions were trans- formed into Lyceums in 1937, reinforcing the French influence in its origins. In 1941, the Brazilian VET system encompassed teaching training programs and industrial, commercial, and agricultural technical programs, and students could access these programs through specialized exams. It is in this context that vocational and technical education became equivalent to secondary education in Brazil.

In 1942, the productive sectors started to create their vocational education schools. The first one established in Brazil was the National Service for Industrial Apprenticeship (SENAI), which was highly influenced by the German and Swiss Dual Vocational System (Gonon, 2014). As they are known nowadays, the S System encompasses nine institutions to promote qualification and access to leisure and cultural activities for Brazilian workers and are funded by specific levies.

Since then, the country coexists with two streams into the Brazilian Vocational System. The Federal one, public, is funded only by the government, with free education for all enrolled students, and the S System, whose schools offer public education with some free programs and others paid for by the students.

In the 1990s, the industrial and agricultural technical schools that attended to the federal government's specific criteria were transformed into Federal Centers of Technological Education (CEFET). Until 1997, only five out of the 44 existing CEFETs had the autonomy to offer higher education programs. The differences in treatment among them also promoted imbalance in institutional developments, creating more massive and more autonomous institutions at one side, and smaller ones at the other which depended on Federal Universities to certify students in VET higher education programs.

At the beginning of President Lula da Silva's first term, the growing dissatisfaction with the government restrictions, as well as the pressure of society to expand the number of enrollments in VET Higher Education, caused the Minister of Education at the time, Fernando Haddad, to promote the transformation of CEFETs into Federal Institutes, creating hundreds of new campuses in unprecedented growth in the number of students and courses. Since then, the Brazilian VET Professional Education has evolved in a parallel model to the university sector (Skolnik, 2016). The parallel model's rising is related to the paradigmatic transition regarding the demand for higher education, which has been seen by the middle class as a positional good that allows social and 
Table 1

Brazilian Federal VET System in Numbers - 2004/2014

\begin{tabular}{lcc}
\hline & 2004 & 2014 \\
\hline Campus & 144 & 652 \\
Institutions & 138 & 40 \\
Funding & 105 billion (US\$) & $\approx 1,700$ trillion (US\$) \\
Students & $\approx 150,000$ & $\approx 1$ million \\
Faculty and staff & $\approx 18,000$ & $\approx 80,000$ \\
\hline
\end{tabular}

economic mobility (Trow, 1999). Table 1 presents some numbers related to Fls that can demonstrate the challenge of expanding the Federal VET System in 10 years.

It is essential to say that the campuses' expansion movement was slightly before Act 11,892/2008 (Brasil, 2008), which constituted the Federal Institutes. These institutions are public, tuition-free, and entirely funded by the government. They enjoy a social quality seal given by the community where their campuses are located, delivering programs strictly related to the economic, cultural, and social development of the region in which they are settled. Despite the students' and employers' recognition of the vital role of these federal institutions, the private sector of professional education (for-profit and S System) still accounted for approximately $41 \%$ of enrollments in the year 2018 because the places are not enough to grant full access to all (Brasil, 2020).

\section{Brazilian and Canadian Coopera- tion: From the A Thousand Women Project to Science Without Borders Program}

Considered the Federal Institutes' first international experience, the A Thousand Women project carried out in partnership with Canadian Colleges and with financial support from Canadian International Development Agency (CIDA) drew FI faculty and staff's attention to the possibilities of interinstitutional cooperation with other countries. The activities in Brazil were implemented by the Secretariat of Professional and Technological Education of the Ministry of Education (SETEC/MEC) from
2005 and counted on several government agencies' participation. This program was established to assist and qualify women professionally in conditions of social vulnerability. Its pilot experiment was developed in Natal with a group of 60 women by the Federal Center of Professional and Technological Education of Rio Grande do Norte - CEFET/RN, nowadays Federal Institute of Education, Science, and Technology of Rio Grande do Norte (IFRN) and Niagara College. After this first stage's success, SETEC/MEC decided to expand the project and the involvement of four other CEFETs in the North and Northeast regions: Bahia, Amazonas, Ceará, and Pará. Again, the experience was successful and in 2007 a new expansion was proposed, this time providing programs in 13 northeastern states and qualifying 1,191 women. The pedagogical and methodological approach of A Thousand Women lay in Prior Learning Assessment and Recognition (PLAR) (Morrissey et al., 2008). The collaboration between the countries enabled the training of teachers to work with students, missions to Canada to learn about the realities of Colleges, trips to Brazil to evaluate the programs, seminars, videos, interviews, and even the sale in Canada of some of the artisanal products made by the students. The social and emotional repercussions of this experience are described in some papers and videos available on the internet (Association of Canadian Community Colleges [ACCC], 2014; Brasil, 2011a, 2011b).

Through PLAR, teachers, tutors, and staff were trained to incorporate these women's knowledge, restore their self-esteem and cultural values, and provide them with a new meaning for the educational process. Brazilian women enrolled in such initiatives developed institutional actions such as Food for Social Inclusion, 
Tilapia House, ${ }^{2}$ Citizenship through Art, Community Development, and Dressing up Citizenship (Brasil, n.d.).

The project's relevant social impact expanded to Brazil in 2014 (A Hundred Thousand Women) (Brasil, 2011b). The exchanging of pedagogical approach influenced other educational proposals at Federal Institutes, such as the Certific Network, which brought recognition of prior learning and professional certification to the programs (Brasil, 2009). The initiative also inspired hundreds of research projects, theses, dissertations, and papers where its outcomes can be perceived.

Although the relationship between the Federal Institutes and Canadian Colleges dated back to 2007 and started with the $A$ Thousand Women project, the much closer relationship between the National Council for the Federal Network of Vocational, Scientific, and Technological Educational Institutions (CONIF) and the Colleges and Institutes Canada (CiCan) began in 2011, after the massive demand for the student and faculty mobility promoted by Science without Borders (SwB). At the beginning of 2013, both associations structured a proposal for publicizing Canada among Brazilian institutions, and in June of that year a group of approximately 30 Canadian international advisors, divided into five sub-groups to meet all Brazilian regions, came to the country for an agenda of promoting the possibilities of education in Canada. As a result, the Coordination of Superior Level Staff Improvement (CAPES) prepared a specific public call for students at Federal Institutes to go to Canadian Colleges, thus enabling different qualification perspectives for these students (Brennan, 2014).

This mission's effects were so promising that Canada has remained among the Federal Network students' top four destinations for mobility programs. The number of scholarships granted to students at Fls, when the Science without Borders Program was active as a governmental program, can demonstrate their preferences. From 2011 to 2017, MEC afforded 2,995 scholarships to students from Federal Institutes. The first destination chosen by students was the United States, with 952 scholarships awarded. Canada was the second choice, with 497 scholarships $^{3}$. From 2017 on, with the extinction of funding for international mobility, Brazilian Federal Institutes have had difficulties maintaining scholarships for their students. However, there are experiences of Internal Mobility Programs in some institutions that are still operational.

\section{The Social Worlds Related to the Federal Institutes}

Following Grounded Theory (GT) guidelines, the research data were first analyzed in open coding and later in selective coding. While scanning the interviews conducted throughout the research and the questions that were asked about the Fls' internationalization process, two distinctive patterns stood out.

The first one recounts the interviewees' perception of the constitution of a FI unique identity, built fundamentally by three institutional characteristics: diversity (meaning coexistence between the differences), opportunity (as a possibility of social mobility), and resistance (as an exercise of will, choice, and conscience of the historical movement) (Freire, 2004). Resistance to topdown reforms is essential for these institutions and can be viewed as a process of policy implementation's adequacy, causing actors to flexibilize and translate norms according to their local context (Ball, 2012; Maurer \& Gonon, 2014). These traits are intertwined with an inland flow, which takes the Federal Institutes to areas far from large urban centres. The references to these Federal Institutes' features were preeminent and configured the World of the Federal Institutes Unique Identity (Figure 1$),{ }^{4}$ which is not concrete in actions. Instead, it is a conception that emerged from the interviews, being a differentiation element of these institutions in their relationship with the other Social Worlds. The interviews showed that this construction arises through individual and institutional learning/teaching/sharing actions, which are also present in the relationships established with their international partners.

The second point that stood out in the data analysis, which is the main object of this article, was the World of Canada configuration that overlaps the World of Internationalization and the World of Federal Institutes. Figure 1 shows the graphical representation of data analysis produced by the interviews. It also presents the worlds that interact in the Brazilian Professional Education Arena concerning the theme of internationalization.

Mapping the relationalities and positionalities between the actors, strategies, and historical facts delineated the Federal VET Network's internationalization. They are connected to the Social Worlds with dashed squares and were located according to their association with each world. Some of them are peripheral, interact- 
ing more with one world than with the other, as in the case of the Organization of Ibero-American States (OEI) and the Brazilian Agency of Cooperation (ABC). Others have more robust connections and overlap with each other, as SETEC, CiCan, and CONIF.

By the interviewees' discourse intensity (85 references along 11 interviews), Canada can be analyzed as a Social World since it interacts with the Federal Institutes through organizations, funding agencies, educational institutions, mobility programs, and joint partnerships for teaching, research, and extension. The $A$ Thousand Women project, although 15 years long, notably stands out for Brazilian institutions (22 references). The excerpts below can show the importance of the project and the relationship established with the Canadian Colleges.

We started to expand the A Thousand Women project. It was this project that made it possible for us to exchange with Canada, right? And then we've begun the mission process. We participated in the first three missions taking rectors, professors, network leaders to get to know Canadian Colleges. And we also received partners from Canada to get to know the Federal Network. (Former Rector A) ${ }^{5}$

A Thousand Women is perhaps the most prominent symbol of this, as well. Because A Thousand Women project, as part of an international cooperation project, is full of life. It was tested in 13 different contexts. So, it was a public policy project based on Canadian experience that later became public policy at a national level. I would say that I do not know another international cooperation experiment with this degree of commitment and depth. (MEC Staff C)

The professionals interviewed consider this experience the milestone of the Federal Network's internationalization, and their memories are impacted by it. Some of the participants describe it this way:

So, when we got there [in Canada], we saw the project's dimension, the international dimension. And we saw the possibility of internationalizing our CEFET more. We came back [to Brazil], and several situations were happening. (International Advisor C)

Get in there, the first actions back there, with our CONIF president at that time. He began to talk to
Canada more intensely because, until then, we had only one project. I think it was our single internationalization experience, which was $A$ Thousand Women, developed with Canada. (Rector C)

SETEC was also a valuable political player in the cooperation between Canada and Brazil. It functions as an articulating and regulatory body of the Brazilian government for professional education, being under its responsibility the main streams of VET in the country: The S System and the Federal EPT Network. As the main actor inducing and financing the Federal Institutes and, consequently, their internationalization, it appears in the Map with more defined lines, interacting with the World of Federal Institutes, World of Internationalization, and World of Canada. During the creation of the Fls, this Secretariat was strategic for discussing the implementation proposal and supporting campuses' expansion. It was also the chief articulator of the $A$ Thousand Women project, funding seminars, publications, and evaluations of the outcomes. According to Dolowitz and Marsh (1996), financial and political support for implementing a policy is a determining factor for its success or failure. As Knight (2012) noted, there is a multiplicity of institutions and organizations involved in internationalization, each with its specific nature and role and related to its intrinsic mission. The author defines this process's actors in terms of level (international, national, bilateral, inter-regional, and sub-regional), typology, and roles. Sometimes they can overlap their actions and performances. As international activities' scope and diversity expand, the lines between these levels become more fluid and permeable. Thus, SETEC had a decisive role in inserting the lessons learned from the project in the institutions' daily lives.

It is possible yet to observe other Canadian actors interacting in the internationalization process of the Federal Institutes. The country was also mentioned in six out of 14 interviews by the Colleges and Institutes Canada (CiCan) and in two others by the Canadian International Development Agency (CIDA). The World Federation of Colleges and Polytechnics (WFCP), whose head office is located in Ottawa, Canada, is another relevant actor, with mentions in seven interviews. WFCP stands out as one of the protagonists for the more significant insertion of Federal Institutes in the World of Internationalization. The Brazilian Federal VET Network was introduced to this association by CiCan and stuck out due to its size 
and the international visibility provided by the Science without Borders Program. Concerning this moment, Rector $C$ said that "entering WFCP made a difference.... Strengthened both groups."

Former Rector A echoed Rector C about that particular time:

Soon after, when we entered CiCan, at the time ACCC, the creation of the World Federation of Colleges and Institutes, the WFCP, begins. Some points were converging. After this, things suddenly started because the visibility became too high.

Besides WFCP, other international organizations gained relevance for the Federal VET Network's internationalization process through Canadian partners. CiCan introduced UNEVOC_-International Center for Technical and Vocational Education and Training, a UNESCO branch for Vocational and Education Training-to Brazilian Federal Institutes, which resulted in a partnership with CONIF for a Brazilian headquarter.

Not only were actors relevant to the conception of the World of Canada, but institutional strategic actions were also necessary when developing internationalization planning. According to Knight (2005), institutions develop international strategies to achieve their goals more effectively. As we could observe from the research data, the Federal Institutes are involved mainly in cross-border activities, including prospecting for partnerships, participation in International Organizations, delivering or receiving training courses, and developing joint research projects. These actions are related to what the participants named as a learning/teaching/sharing proceeding aligned to the Federal Institutes' Unique Identity and is part of their international praxis.

Former Rector A expressed this perception, saying:

I think, today, the Federal Institute has a model of our own, a model coined by us, which nowadays serves as a reference for the world. The moment we showed it to the world, and Canada was our first great international experience, in our partnership with Colleges, we have already mirrored it, so that today Community Colleges are considered Canadian Institutes, you know?

Another research participant, an International Advisor, describes the internationalization process this way:
To internationalize is to participate in the world, to be a global actor where you share and learn and teach as well. We taught Canadians many things. We were together on the project. We learned from them those learning assessment and recognition tools and developed the Certific Network. So they taught us, but they also learned a lot from us. Internationalization is present as we are making lives or chats through digital media. The world today is on a tablet or at your hands on a mobile phone. So communicating is necessary and thinking about the world to break boundaries and barriers is also necessary. So we grow together as nations.

This cooperation that began with the A Thousand Women project, and which was, in a way, a sharing of best practices, extended to other cooperation strategies. Three formal meetings for VET networking development took place between Canada and Brazil, the first one in Rio de Janeiro (2010), the second in Montreal (2011), and the third in Salvador, Bahia (2013). These actions contributed to 51 Memoranda of Understanding (MOUs) signed between Brazilian Federal Institutes and Canadian Community Colleges. Nowadays, there are 14 operational cooperation projects. As an example, we can name the Federal Institute of Science and Technology of Rio Grande do Sul (IFRS) and Cégep de Sherbrooke, Quebec, that have been developing joint projects since 2011 in biotechnology, agriculture, and water fields. Another action is the partnership between the Federal Institute of Science and Technology Sul-Riograndense, located in Rio Grande do Sul, and Camosun College, British Columbia, to record videos for an online English language teaching program (E-Tec Language), which is available to all Federal Institutes of Brazil.

In addition to these bilateral initiatives, SETEC established an MOU with CiCan in 2013 for teacher training in Canada. It was a pilot project for internships in Canadians Colleges, where 43 professors were tasked with understanding colleges' relationships with companies. This first project opened up possibilities for the same strategy to be replicated with Finland a year later.

These experiences provided an internationalization culture awareness in Brazilian institutions and served as models for other institutional projects. Asked about internationalization benefits, a former Ministry of Education International Advisor thus manifests how this activity im- 
pacted the institutions:

The third is that I think it greatly enriches the portfolio of the institution. You will not necessarily have the same practical outcome on reproducing a course with that experience, with that involvement, but the institution begins to experience different aspects of what it was used to. To mention to you an inspiring example: from the cooperation with Canada, The Federal Institute of Rio Grande do Norte began to offer immersion courses in the Portuguese language and Brazilian culture for foreigners. They would hardly have experienced the presence of foreigners on campus in any other way.

As we could note from the analysis carried out by the research, there is a clear understanding of the strategic features of internationalization among the participants, leading the institutions to learn and share enjoyable experiences. This comprehension enables international actions to occur sustainably and the mobility of faculty, staff, and students to be a consequence of them and not an end in itself (Knight, 2012).

\section{Conclusion}

This article's conception began with evaluating the available data from a research project that had as its primary objective the elicitation of interviewees' thoughts about the Federal VET Network's internationalization model in Brazil. Using Situational Analysis as a methodological tool, it was possible to configure the Social Worlds that interact in the researched situation and to realize as fundamental for Fl's internationalization process the partnership established between Canada and Brazil from the A Thousand Women program.

The relations between the World of Federal Institutes and the World of Canada, which were based on the interviewees' perceptions, evidenced what Knight (2004) pointed out about the essential role of development of strategic alliances and networks to institutions in their internationalization movement, since they can provide the achievement of academic, scientific, technological, or cultural goals. The data also allow us to recognize the presence of the four pillars necessary for the experiences of international programs to be successful, that is, leadership for perceiving the potential of these exchang- es and mobilizing the efforts of the academic community for them, the engagement with the projects developed, and the political and financial support of the governance for their accomplishment (Nolan \& Hunter, 2012).

The first international experience of the Federal Institutes, the A Thousand Women project, is very much alive in the interviewees' speech, as other strategies developed with Canadian partners, which ensures that relations between the two Worlds remain solid even today. As an example, we can cite the preference of Brazilian FIs' students for Canada as a destination country, even if it is not among the top 10 destinations chosen by Latin American and Caribbean students (Gacel-Ávila \& Rodríguez-Rodríguez, 2018), which can demonstrate that there is a real synergy between the two countries. Cana$\mathrm{da}$ is also the second country in cooperation agreements with Brazilian Federal Institutes, only behind Portugal, which signals that institutions have built reliable and productive partnerships, producing concrete benefits for institutions, such as enhancing international cooperation and solidarity.

As north-south cross-border cooperation, the partnership established between Canada and Brazil through their cooperation agencies, governance, and educational institutions could have reproduced the dominant pattern of internationalization, presenting what Knight (2012) calls unintended consequences or risks of internationalization, such as brain drain, competition, marketing, and elitization of educational opportunities. On the contrary, what can be seen is that this international experience built a cooperative and collaborative network between Canadian and Brazilian institutions, respecting the institutional and cultural characteristics of the institutions and supporting the claims that the success of any international initiative or transfer lies in these rationales (Knight, 2017). Underlying this fruitful history of cooperation is the concept of production and reproduction of knowledge through social experience that implies the coexistence and construction of various epistemologies that make a social experience understandable or meaningful. It means that there are no conditions of building knowledge without the existence of social subjects and practices, which, in turn, are inherent to social relations.

These findings can identify at least two challenges for future research. Firstly, professional education institutions are fundamental to the debate around the varieties of capitalism because they mediate the hierarchical 
relations between work and society. If we take Brazil and Canada as examples of countries of the Liberal Market Economies, it would be important that future research could deepen the reasons this cooperative relationship escaped the usual competitive interaction pattern. There are significant differences in structure, language, management, programs, recruitment, and qualifications between Brazil and Canada, but these variations were not considered obstacles to establishing new partnerships and cooperation. So it is crucial to understand what lies beneath this discrepancy.

Secondly, looking at the way the partnership between Brazil and Canada developed from the A Thousand Women program, this experience could offer a stimulating basis of research for the literature of the transfer of educational policies, deepening understanding of how the dynamics of the political and economic context occurred within this international experience, as well as the relations between the actors involved (institutions, government, and cooperation agencies).

In any case, it is possible to claim that, regarding the partnership between the Brazilian and Canadian professional institutions, the respect for the local context, the customizing of the transfer process (Knight, 2017), and the commitment to the strategies by the actors involved in the program (Dolowitz \& Marsh, 1996; Steiner-Khamsi, 2012) all contributed to a situation in which the outcomes of this bilateral cooperation could be rooted in the institutional imaginary. The data analyzed in this article support the assumption that Canada became the international milestone for the Brazilian Federal Institutes, which helped them build their internationalization process, conceiving it reliably and concretely.

\section{Acknowledgements}

I would like to thank Leesa Wheelahan for guiding me through the VET literature world and Paul Brennan for writing the French abstract.

\section{References}

Association of Canadian Communities and Colleges (ACCC). (2014). Brazil's 1000 Women Project: Education, citizenship and sustainable development [Video]. Ottawa, ACCC. https://www.youtube.com/ watch?v=sHRtoaSqlj4
Altbach, P. G., \& Knight, J. (2007). The internationalization of higher education: Motivations and realities. Journal of Studies in International Education, 11(3-4), 290-305. https://doi.org/https://doi. org/10.1177/1028315307303542

Ball, S. J. (2012). Global education inc.: New policy networks and the neoliberal imaginary. Routledge.

Bosch, G., \& Charest, J. (2009). Vocational training: International perspectives. In G. Bosch \& J. Charest (Eds.), Vocational training: International perspectives (pp. 1-26). Routledge. https://doi. org/10.4324/9780203869574

Brasil. (n.d.). Projetos Mulheres Mil na Rede Federal. Mulheres Mil. http://mulheresmil.mec.gov.br/transformacao-cidadania-e-renda

Brasil. (1909). Decreto n. 7566, 23 set. 1909, RJ. Crêa nas capitaes dos Estados da Republica Escolas de Aprendizes Artifices, para o ensino profissional primario e gratuito. https://www2.camara.leg.brl legin/fed/decret/1900-1909/decreto-7566-23-setembro-1909-525411-publicacaooriginal-1-pe.html

Brasil. (2008). Lei $n^{0} 11.892$, de 29 de dezembro de 2008. Institui a Rede Federal de Educação Profissional, Científica e Tecnológica, cria os Institutos Federais de Educação, Ciência e Tecnologia, e dá outras providências. Diário Oficial da União. http:/l www.planalto.gov.br/ccivil 03/ ato2007-2010/2008/ lei//11892.htm

Brasil. (2009). Portaria Interministerial nr 1082, de 20 de novembro de 2009. http://www.adur-ri.org. br/4poli/gruposadur/gtpe/portaria interministerial $1082 \quad 20 \quad 11 \quad 09 . h t m$

Brasil. (2011a). Mulheres Mil [Documentary]. https://youtu.be/kEAFeW4M3WE

Brasil. (2011b). Mulheres Mil na Rede Federal: Caminhos da inclusão. SETEC/MEC. http://mulheresmil. mec.gov.br/images/stories/pdf/geral/mulheres mil na rede federal - caminhos da inclusao.pdf

Brasil. (2020). Censo da Educação Básica 2019. Instituto Nacional de Estudos e Pesquisas Educacionais Anísio Teixeira (INEP). https://download.inep.gov.br/publicacoes/institucionais/estatisticas e indicadores/resumo tecnico censo da educacao basica 2019.pdf 
Brennan, P. (2014). Raising the quality and image of TVET: Lower-level training or motor for inclusive and sustainable growth? Prospects, 44(2), 183-195. https://doi.org/10.1007/s11125-014-9312-3

Cantwell, B., Marginson, S., \& Smolentseva, A. (2018). High participation systems of higher education (1st ed.). Oxford University Press. https://doi. org/10.1093/oso/9780198828877.001.0001

Clarke, A. E., Washburn, R., \& Friese, C. (2018). Situational analysis: Grounded theory after the interpretive turn (2nd ed.). SAGE Publications.

Dale, R. (2000). Globalization and education: Demonstrating a "common world educational culture" or locating a "globally structured educational agenda"? Educational Theory, 50(4), 427-448. https://doi. org/10.1111/j.1741-5446.2000.00427.x

De Wit, H., Gacel-Avila, J., Jones, E., \& Jooste, N. (2017). The globalization of internationalization: Emerging voices and perspectives. Routledge. https://doi.org/10.4324/9781315657547

Didriksson, A. (2008). Contexto global y regional de la educación superior en América Latina y el Caribe. In A. L. Gazzola \& A. Didriksson (Eds.), Tendencias de la Educación superior en América Latina y el Caribe (pp. 21-54). IESALC-UNESCO. http://flacso. redelivre.org.br/files/2012/08/753.pdf

Dolowitz, D., \& Marsh, D. (1996). Who learns what from whom: A review of the policy transfer literature. Political Studies, 44(2), 343-357. https://doi. org/10.1111/j.1467-9248.1996.tb00334.x

Freire, P. (2004). Pedagogy of indignation (1st ed.). Routledge. https://doi.org/10.4324/9781315632902

Gacel-Ávila, J., \& Rodríguez-Rodríguez, S. (2018). Internacionalización de la educación superior en América Latina y el Caribe: un balance. Universidad de Guadalajara. http://obiret-iesalc.udg.mx/es/publicaciones-propias/internacionalizacion-de-la-educacion-superior-en-america-latina-y-el-caribe-un

Gonon, P. (2014). Development cooperation in the field of vocational education and training: The dual system as a global role model. In M. Maurer \& P. Gonon (Eds.), The challenges of policy transfer in vocational skill development. National qualifications frame- works and the dual model of vocational training in international cooperation. (pp. 241-259). Peter Lang. https://doi.org/10.3726/978-3-0351-0758-6

Greinert, W.-D. (2010). Governance models of training for employment: A European perspective. Research in Comparative and International Education, 5(3), 251-260. https://doi.org/10.2304/rcie.2010.5.3.251

Hall, P. A., \& Soskice, D. (2001). Varieties of capitalism: The institutional foundations of comparative advantage. Oxford University Press. https://doi.org/10.109 3/0199247757.001.0001

Helms, R. M., Rumbley, L. E., Brajkovic, L., \& Mihut, G. (2015). Internationalizing higher education worldwide: National policies and programs. American Council on Education https://www.researchgate.net/ publication/313428029 Internationalizing Higher Education Worldwide National Policies and Programs

Knight, J. (2004). Internationalization remodeled: Definition, approaches, and rationales. Journal of Studies in International Education, 8(1), 5-31. https://doi. org/10.1177/1028315303260832

Knight, J. (2005). An internationalization model: Responding to new realities and challenges. In $\mathrm{H}$. de Wit, I. C. Jaramillo, J. Knight, \& J. Gacel-Ávila (Eds.), Higher education in Latin America: The international dimension (pp. 1-38). The World Bank. https://doi.org/10.1596/978-0-8213-6209-9

Knight, J. (2012). Concepts, rationales, and interpretive frameworks in the internationalization of higher education. In D. K. Deardoff, H. de Wit, J. D. Heyl, \& T. Adams (Eds.), The SAGE handbook of international higher education (pp. 27-42). SAGE Publications. https://doi.org/10.4135/9781452218397.n2

Knight, J. (2017). Five truths about internationalization: International higher education. In $\mathrm{H}$. de Wit, P. Altbach, \& G. Mihut (Eds.), Understanding higher education internationalization (Vol. 39, pp. 13-15). Sense Publishers. https://doi.org/10.1007/978-94$\underline{6351-161-23}$

Levin, J. S. (2017). Community colleges and new universities under neoliberal pressures: Organizational change and stability. Palgrave MacMillan. https:ll 


\section{doi.org/10.1057/978-1-137-48020-0}

Maurer, M., \& Gonon, P. (2014). The challenges of policy transfer in vocational skills development: An introduction. In M. Maurer \& P. Gonon (Eds.), The challenges of policy transfer in vocational skills development: National Qualifications frameworks and the dual model of vocational education in international cooperation. (pp. 15-35). Peter Lang. https:// doi.org/https://doi.org/10.3726/978-3-0351-0758-6

Morosini, M. C., \& Dalla Corte, M. G. (2018). Teses e realidades no contexto da internacionalização da educação superior no Brasil. Revista Educação Em Questão, 56(47), 97-120. https://doi. org/10.21680/1981-1802.2018v56n47ID14000

Morrissey, M., Myers, D., Belanger, P., Robitaille, M., Davison, P., Van Kleef, J., \& Williams, R. (2008). Achieving our potential: An action plan for prior learning assessment and recognition (PLAR) in Canada. PLA Centre. https://files.eric.ed.gov/fulltext/ ED505872.pdf

Nolan, R., \& Hunter, F. (2012). Institutional strategies and international programs: Learning from experiences of change. In D. K. Deardoff, H. de Wit, J. D. Heyl, \& T. Adams (Eds.), The SAGE handbook of international higher education (pp. 131-146). SAGE Publications. https://doi.org/10.4135/9781452218397.n8

Raffe, D. (2008). The concept of transition system. Journal of Education and Work, 21(4), 277-296. https:/l doi.org/10.1080/13639080802360952

Skolnik, M. L. (2016). Situating Ontario's colleges between the American and European models for providing opportunity for the attainment of baccalaureate degrees in applied fields of study. Canadian Journal of Higher Education, 46(1), 38-56. https:/l doi.org/10.47678/cjhe.v46i1.185954

Steiner-Khamsi, G. (2012). Understanding policy borrowing and lending: Building comparative policy studies. In G. Steiner-Khamsi \& F. Waldow (Eds.), World yearbook of education 2012 (pp. 3-17). Routledge. https://doi.org/doi. org/10.4324/9780203137628

Tran, L. T., \& Dempsey, K. (2017). Internationalization in vocational education and training: transnation- al perspectives (Vol. 25). Springer. https://doi. org/10.1007/978-3-319-47859-3

Trow, M. (1999). From mass higher education to universal access: The American advantage. Minerva, 37(4), 303-328. https://doi. org/10.1023/A:1004708520977

Waldow, F. (2018). Commentary to part III: Why is "being international" so attractive? "Being international" as a source of legitimacy and distinction. In C. Maxwell, U. Deppe, H.-H. Krüger, \& W. Helsper (Eds.), Elite education and internationalisation: From the early years to higher education (pp. 247-253). Springer International Publishing. https://doi. org/10.1007/978-3-319-59966-3 15

Wheelahan, L., \& Moodie, G. (2017). Vocational education qualifications' roles in pathways to work in liberal market economies. Journal of Vocational Education \& Training, 69, 10-27. https://doi.org/10.1 080/13636820.2016.1275031

Wheelahan, L., \& Moodie, G. (2018). What should vocational qualifications look like if the links between qualifications and jobs are so weak? In S. Allais \& Y. Shalem (Eds.), Knowledge, curriculum and preparation for work (pp. 127-146). Brill Sense. https://doi. org/10.1163/9789004365407 008

Wollschlager, N., \& Reuter-Kumpmann, H. (2004). From divergence to convergence: $A$ history of vocational education and training in Europe. European Journal: Vocational Training, 32, 6-17. https://www.cedefop. europa.eu/files/32-en.pdf

\section{Contact Information}

Claudia Schiedeck Soares de Souza

claudia.souza@bento.ifrs.edu.br

\section{Notes}

1 The expressions of Professional Education and VET are used here in this article interchangeably because they are used this way in Brazil.

2 Tilapia is a common freshwater native to Africa but has been introduced in many places in the open waters of South America (e.g., southern and southeastern Brazil) 
and southern North America (e.g., Florida and Texas).

3 The system of choosing the destination country in the Science without Borders Program was exclusive to the student. Although teachers could facilitate contacts between students and partner institutions, the choice was personal.

4 Please see Figure 1 by clicking here.

5 The participants' statements used in this article were translated into English by this author, keeping their original meaning. 